\title{
KATEGORI PERKAWINAN BELUM TERCATAT DALAM BLANGKO KARTU KELUARGA PERSPEKTIF YURIDIS
}

\author{
Amanda Zubaidah Aljarofi
}

Tulungagung Jawa Timur. E-mail: amandazu321@gmail.com

\begin{abstract}
This article discusses marital status in a family card that has a registered marriage and an unregistered marriage. The important question to be answered through this article is that the legal basis for making the marriage category has not been recorded as one of the marital status in the family card blank. The analysis is carried out using the applicable laws and regulations namely Law Number 1 of 1974 concerning Marriage, Government Regulation Number 9 of 1975 concerning Implementation of Law Number 1 of 1974 concerning Marriage, Compilation of Islamic Law, and Regulation of the Minister of Religion of the Republic of Indonesia Number 19 of 2018 concerning Marriage Registration. Changes in marital status in family card blanks regulated in Minister of Domestic Affairs Regulation Number 118 of 2017 concerning Family Card Blanks, Registration and Quotation of Civil Registration Deed, caused the Directorate General of Population and Civil Registration of the Ministry of Home Affairs of Indonesia to make the development of the population database change to $S L A K$ 7. This change has caused the registration of marriages which initially functioned to guarantee legal order as instruments of legal certainty through proof of marriages, to be disorderly in the law. It is because in the long-term marriages have not been recorded and remain facilitated by the state through fulfillment of administrative rights.
\end{abstract}

Keywords: unregistered marriage, family card blank, and marriage registration

\begin{abstract}
Abstrak: Artikel ini membahas status perkawinan dalam kartu keluarga yang tertulis kawin tercatat dan kawin belum tercatat. Pertanyaan penting yang ingin dijawab melalui artikel ini adalah dasar hukum dijadikannya kategori perkawinan belum tercatat sebagai salah satu status perkawinan dalam blangko kartu keluarga dan dijadikannya kategori perkawinan belum tercatat sebagai salah satu status perkawinan dalam blangko kartu keluarga. Analisis dilakukan dengan menggunakan peraturan perundang-undangan yang berlaku yakni UU Nomor 1 Tahun 1974 Tentang Perkawinan, Peraturan Pemerintah Nomor 9 tahun 1975 tentang Pelaksanaan UndangUndang Nomor 1 Tahun 1974 Tentang Perkawinan, Kompilasi Hukum Islam, dan Peraturan Menteri Agama Republik Indonesia Nomor 19 Tahun 2018 Tentang Pencatatan Perkawinan. Perubahan status perkawinan dalam blangko kartu keluarga yang diatur dalam Peraturan Menteri Dalam Negeri Nomor 118 Tahun 2017 Tentang Blangko Kartu Keluarga, Registrasi dan Kutipan Akta Pencatatan Sipil menyebabkan Direktorat Jenderal Kependudukan dan Pencatatan Sipil Kementerian
\end{abstract}

AL-HUKAMA

The Indonesian Journal of Islamic Family Law Volume 09, Nomor 02, Desember 2019; ISSN:2089-7480 
Dalam Negeri Indonesia membuat pengembangan database kependudukan berganti menjadi SIAK 7. Perubahan tersebut menyebabkan kedudukan pencatatan perkawinan yang semula berfungsi untuk menjamin ketertiban hukum (legal order) sebagai instrumen kepastian hukum melalui alat bukti perkawinan, menjadi tidak tertib hukum karena dalam jangka panjang perkawinan belum tercatat tetap difasilitasi negara melalui pemenuhan hak administratif kependudukan.

Kata Kunci: perkawinan belum tercatat, blanko kartu keluarga, dan pencatatan perkawinan.

\section{Pendahuluan}

Definisi perkawinan menurut pasal 1 Undang-Undang Nomor 1 Tahun 1974 tentang Perkawinan adalah ikatan labir batin antara seorang pria dewasa dengan seorang wanita sebagai suami istri dengan tujuan membentuk keluarga (rumah tangga) yang bahagia dan kekal berdasarkan Ketuhanan Yang Maha Esa.1 Langgengnya kehidupan dalam ikatan perkawinan merupakan tujuan yang sangat diutamakan dalam Islam. Pernikahan diadakan untuk selamanya agar suami istri dapat bersama-sama mewujudkan rumah tangga sebagai tempat berlindung, menikmati curahan kasih sayang dan memelihara anakanak agar tumbuh dengan baik. Oleh karena itu, dapat dikatakan bahwa ikatan antara suami-istri adalah ikatan yang paling suci dan paling kokoh.2

Dalam Undang-Undang Nomor 1 Tahun 1974 Tentang Perkawinan, dinyatakan, bahwa perkawinan adalah sah bila dilakukan menurut hukum dan kepercayaan dan di samping itu tiaptiap perkawinan harus dicatat menurut peraturan perundangundangan yang berlaku.3 Artinya, perkawinan akan dianggap sah bila dilakukan menurut hukum dan kepercayaan yang dianut oleh calon mempelai. Prinsip ini mengedepankan keseimbangan (kafäab) agama sebagai dasar untuk melakukan perkawinan. Kedua calon mempelai harus seagama atau seiman, kecuali hukum agama atau kepercayaannya menentukan lain.

1 Undang-Undang Republik Indonesia Nomor 1 Tahun 1974 Tentang Perkawinan dan Kompilasi Hukum Islam (Jakarta: Gramedia Press, 2014), 2.

2 Slamet Abidin, Fiqih Munakahat (Bandung: Pustaka Setia, 1999), 9.

3 Undang-Undang Nomor 1 Tahun 1974 Tentang Perkawinan, 2. 
Tiap-tiap perkawinan yang dilakukan menurut hukum masingmasing agama dan kepercayaannya itu akan dianggap mempunyai kekuatan hukum bila dicatat menurut peraturan perundangundangan yang berlaku. Pencatatan tiap-tiap perkawinan adalah sama halnya dengan pencatatan peristiwa-peristiwa penting dalam kehidupan seseorang, misalnya kelahiran, kematian yang dinyatakan dalam surat-surat keterangan, suatu akta yang juga dimuat dalam daftar pencatatan. 4

Pencatatan perkawinan dalam tradisi Islam termasuk ketentuan baru, baik Alqur'an maupun hadis tidak menyebutkan secara tegas tentang keharusan pencatatan perkawinan. Hal ini berbeda dengan transaksi mu'amalah yang di dalam Alqur'an diperintahkan untuk mencatatnya. Seiring dengan perkembangan zaman, keberadaan alat bukti otentik perkawinan menjadi suatu kebutuhan. Jika dalam mu'amalah yang diakadkan adalah barang, maka dalam akad nikah yang diakadkan adalah diri sendiri yang diikat tali perkawinan dengan orang lain. Akad perkawinan juga menimbulkan hak dan kewajiban yang lebih luas dari akad mu'ämalah. Hak dan kewajiban yang timbul tidak hanya antara suami dan istri, tetapi juga antara suami istri dengan anak-anak, cucu-cucu dan keluarganya. Tidak hanya saat suami istri masih hidup, bahkan hak dan kewajiban itu muncul setelah meninggal dunia, seperti waris mewarisi, hubungan kerabat dan mahram. 5

Secara teoretis, kasus perkawinan yang tidak tercatat dapat dimintakan ithbät al-nikāh (pengesahan nikah) ke Pengadilan Agama. Perkawinan yang tidak dicatat ini seringkali adalah perkawinan poligami yang tidak mendapatkan izin dari Pengadilan Agama dan sebagian lagi karena ketidaktahuan prosedur yang berlaku atau karena tidak memiliki biaya yang cukup untuk mengurus surat menyurat.6

4 Amir Syarifuddin, Hukum Perkawinan Islam Indonesia Jakarta: Prenada Media, 2006), 25.

5 Ita Musarrofa, Pencatatan Perkawinan di Indonesia (Surabaya: UIN Sunan Ampel Press, 2014), 36.

6 Mukhtamar Zamzami, Perempuan dan Keadilan Dalam Hukum Kewarisan Indonesia (Jakarta: Kencana Prenada Media Group, 2013), 114. 
Setelah melakukan pencatatan perkawinan, suami istri akan memiliki akta nikah sebagai bukti otentik atas perbuatan hukum yang telah mereka lakukan. Apabila terjadi perselisihan atau salah satu pihak tidak bertanggung jawab, maka suami atau istri dapat melakukan upaya hukum guna mempertahankan atau memperoleh hak masing-masing. Walaupun belum sampai menjadikan pencatatan sebagai syarat sahnya perkawinan, namun para ulama diberbagai negara Islam membenarkan kriminalisasi terhadap perkawinan yang tidak dicatat, di antaranya Yaman Selatan menetapkan hukuman denda maksimal 200 dinar, Yordania menetapkan hukuman penjara berdasarkan Jordanian Penal Code (UU Hukum Pidana Yordania) dan denda maksimal 1000 dinar.7

Pada kenyataannya, tidak semua masyarakat Islam di Indonesia mengikuti prosedur atau aturan yang berlaku. Hal ini terbukti bahwa sebagian masyarakat masih melaksanakan praktik nikah yang tidak tercatat secara resmi di hadapan Petugas Pencatat Nikah (PPN) dan Kantor Urusan Agama (KUA) yang dikenal dengan sebutan nikah "sirri" dan sebagian ada yang menyebutnya nikah agama atau nikah di bawah tangan. Perkawinan "sirri" merupakan perkawinan memiliki dampak negatif terutama bagi pihak isteri dan anak-anak hasil dari perkawinan "sirri" tersebut. Hal itu terjadi karena perkawinan "sirri" dari sudut pandang agama adalah sah, namun jika dipandang dari segi perlindungan hukum dan tanggung jawab secara ekonomi serta pendidikan anak-anaknya masih perlu ditinjau ulang. Seorang istri yang dinikahi secara sirri, jika mempunyai masalah dalam perkawinannya, seperti diperlakukan semena-mena oleh suami, tidak memiliki kekuatan hukum sebagaimana perkawinan yang tercatat secara resmi di Kantor Urusan Agama, karena perkawinan mereka tidak mempunyai bukti tertulis. 8

Perkawinan juga menentukan kedudukan hukum, peranan dan tanggung jawab anak dalam keluarga. Secara normatif, orang tua memiliki kewajiban hukum sebagai perwujudan tanggung jawab terhadap anaknya untuk membiayai kehidupan sandang, pangan dan

7 Ibid.,114.

8'Tsuroya Kiswati, et al., Perkawinan di Bawah Tangan (Sirri) dan Dampaknya Bagi Kesejabteraan Istri dan Anak di Daerah Tapal Kuda Jawa Timur (Surabaya: Pusat Studi Gender IAIN Sunan Ampel, 2003), 151. 
pendidikan selama anak-anak tersebut masih belum dewasa. Walaupun perkawina "sirri" dianggap sah menurut agama Islam, namun perkawinan tersebut juga harus sah secara hukum negara. Tanpa adanya pencatatan secara hukum, maka anak-anak yang lahir dari perkawinan tersebut tidak dapat dibuktikan secara hukum merupakan anak sah dari ayahnya. Akibatnya, si anak hanya memiliki hubungan hukum dengan ibu yang melahirkannya.9

Pasal 42 Undang-Undang Nomor 1 Tahun 1974 tentang Perkawinan memberikan definisi bagi anak yang sah yaitu, "anak yang dilahirkan dalam atau sebagai akibat perkawinan yang sah". Dalam pasal $250 \mathrm{KUH}$ Perdata menentukan bahwa, "tiap-tiap anak yang dilahirkan atau ditumbuhkan sepanjang perkawinan, memperoleh si suami sebagai bapaknya". Berdasarkan kedua ketentuan tersebut, keabsahan suatu perkawinan sangat menentukan kedudukan hukum anak-anak yang dilahirkan.10 Dalam kehidupan bermasyarakat di Indonesia, hubungan hukum antara orang tua dengan anak terlihat secara jelas dari kewajiban orang tua terhadap anak dalam mengasuh, memelihara dan mendidik, sampai anakanaknya dewasa atau mampu berdiri sendiri. Bila terjadi perceraian maka pengurusan anak tersebut diputuskan oleh pengadilan. Untuk menjamin kepastian hukum kehidupan bersama dalam tali ikatan perkawinan, agama menetapkan tentang keabsahan perkawinan, sedangkan undang-undang menetapkan keabsahan administratif yang dilakukan oleh negara.

Fungsi dan kedudukan pencatatan perkawinan adalah untuk menjamin ketertiban hukum (legal order) yang berfungsi sebagai instrumen kepastian hukum, kemudahan hukum, dan salah satu alat bukti perkawinan.11 Setiap penduduk wajib melaporkan peristiwa kependudukan dan peristiwa penting yang dialaminya kepada instansi pelaksana, sebab setiap kejadian atau peristiwa penting yang dialami seperti kelahiran, kematian dan perkawinan akan membawa akibat terhadap penerbitan atau perubahan kartu keluarga $(\mathrm{KK})$,

9 Rosnidar Sembiring, Hukum Keluarga Harta-Harta Benda dalam Perkawinan (Jakarta: PT Raja Grafindo Persada, 2016), 126.

10 Ibid., 127.

11Neng Djubaedah, Pencatatan Perkawinan dan Perkawinan Tidak Dicatat Menurut Hukum Tertulis di Indonesia dan Hukum Islam (Jakarta: Sinar Grafika, 2012), 159. 
kartu tanda penduduk (KTP) dan atau surat keterangan kependudukan lain yang meliputi pindah datang, perubahan alamat, atau status tinggal terbatas menjadi tinggal tetap. 12

Dinas Kependudukan dan Catatan Sipil Surabaya merupakan instansi penyedia layanan publik dalam pembuatan administrasi kependudukan salah satunya adalah kartu keluarga. Kota Surabaya sebagai ibu kota provinsi Jawa Timur sekaligus kota metropolitan terbesar kedua setelah Jakarta, memiliki jumlah penduduk sangat banyak sehingga kartu keluraga yang dikeluarkan juga banyak. Bagi pasangan pengantin baru, mengurus administrasi serta dokumendokumen setelah menikah sangatlah penting, terutama dalam memulai rumah tangga. Salah satunya adalah mengurus pembuatan kartu keluarga. Dokumen ini penting untuk pembuatan akta kelahiran bagi anak. Apabila terjadi perubahan kartu keluarga akibat mutasi data atau biodata, maka perlu melaporkan perubahan kepada kelurahan untuk menerbitkan kartu keluarga baru. Kartu keluarga merupakan identitas keluarga yang memuat data tentang susunan, hubungan dan jumlah anggota keluarga.13

Kartu keluarga wajib dimiliki oleh setiap keluarga, dicetak rangkap tiga yang masing-masing dipegang oleh kepala keluarga, ketua Rukun Tetangga (RT) dan kantor kelurahan. Kartu keluarga menjadi dasar untuk penerbitan KTP dan menjadi dasar bagi pemenuhan hak warga negara yang lainnya dan bagi pemerintah menjadi dasar untuk pengambilan keputusan/kebijakan.14 Persyaratan dalam pembuatan kartu keluarga wajib menunjukkan akta perkawinan menyebabkan masyarakat yang tidak mencatatkan perkawinannya atau nikah "sirri" menjadi kehilangan hak administrasi kependudukan.

Akan tetapi, sejak diterbitkannya kebijakan terkait perubahan format baru Kartu Keluarga (KK) yang dijelaskan dalam Peraturan Menteri Dalam Negeri Republik Indonesia Nomor 118 Tahun 2017 Tentang Blangko Kartu Keluarga, Register dan Kutipan Akta Pencatatan Sipil. Setiap perkawinan kini dicatat di kartu keluarga,

12 Fulthoni, et al., Memahami Kebijakan Administrasi Kependudukan (Jakarta: ILRC, 2009), 2.

13 Ibid., 13.

14 Ibid., 13. 
sehingga apabila ada laki-laki atau perempuan mengaku sudah menikah tetapi tidak dapat menunjukkan buku nikah atau akta perkawinannya maka dalam format terbaru kartu keluarga ditulis status kawin belum tercatat. Sementara bagi masyarakat yang mampu menunjukkan akta perkawinannya dalam kartu keluarga akan ditulis status kawin tercatat. Berdasarkan paparan di atas, maka peneliti tertarik untuk membahas lebih dalam tentang dijadikannya kategori perkawinan belum tercatat sebagai salah satu status perkawinan dalam blangko kartu keluarga.

Masalah berkaitan tentang perkawinan belum tercatat atau nikah "sirri" secara umum sebenarnya sudah banyak dikaji, misalnya karya Sholah Hazmi tentang analisis sad al-dhari'ah terhadap perkawinan bawah tangan studi kasus Kelurahan Ujung Kecamatan Semampir Kota Madya Surabaya.15 Contoh lainnya misalnya karya Muizzatil Humairok tantang tinjauan hukum Islam terhadap pemenuhan hak-hak perempuan dalam perkawinan sirri yang ditangani LSM PEKKA.16 Misalnya juga penelitian karya Salman Alfarisi yang membahas tentang komersialisasi pernikahan sirri dalam prespektif hukum islam dan hukum positif studi kasus praktik perkawinan sirri di Desa Pekoren Kecamatan Rembang Kabupaten Pasuruan Provinsi Jawa Timur.17 Sedangkan penelitian yang mengkaji tentang kartu keluarga pernah dilakukan oleh Katrina dengan judul Efektivitas Pelayanan Pembuatan Kartu Keluarga Pada Dinas Kependudukan dan Pencatatan Sipil Kabupaten Tana Toraja.18 Penelitian lainnya misalnya karya Herianto yang berjudul Analisis Hukum

15 Sholah Hazmi, "Analisis Sad Al-Dhari'ah terhadap Perkawinan Bawah Tangan Studi Kasus Kelurahan Ujung Kecamatan Semampir Kota Madya Surabaya" (Skripsi--UIN Sunan Ampel Surabaya,2017).

16 Muizzatil Humairok, "Tinjauan Hukum Islam terhadap Pemenuhan Hak-Hak Perempuan dalam Perkawinan Sirri yang Ditangani LSM PEKKA Bangkalan” (Skripsi--IAIN Sunan Ampel Surabaya, 2012).

17 Salman Alfarisi, "Komersialisasi Pernikahan Sirri dalam Prespektif Hukum Islam dan Hukum Positif (Studi Kasus Praktik Perkawinan Sirri di Desa Pekoren Kecamatan Rembang Kabupaten Pasuruan Provinsi Jawa Timur)" (Skripsi--UIN Sunan Ampel Surabaya,2018).

18 Katrina, "Efektivitas Pelayanan Pembuatan Kartu Keluarga pada Dinas Kependudukan dan Pencatatan Sipil Kabupaten Tana Toraja" (Skripsi-Universitas Hasanuddin,2017). 
Pelaksanaan Pelayanan Kartu Keluarga dan Kartu Tanda Penduduk pada Kantor Dinas Kependudukan dan Catatan Sipil Kabupaten Bone.19 Dari semua penelitian yang pernah dilakukan di atas, kajian tentang penulisan status perkawinan belum tercatat dalam blangko kartu keluarga, belum pernah dilakukan.

\section{Pentingnya Pencatatan Perkawinan}

Syarat sah perkawinan menurut Undang-Undang Nomor 1 Tahun 1974 adalah perkawinan dinyatakan sah apabila dilakukan menurut hukum masing-masing agama dan kepercayaannya. Tiaptiap perkawinan dicatat menurut peraturan perundangan yang berlaku. Artinya orang-orang yang beragama Islam perkawinannya baru sah apabila dilakukan menurut hukum Islam, tetapi di samping itu ada keharusan pencatatan menurut peraturan perundangan yang berlaku. Pencatatan itu diperlukan untuk kepastian hukum, pencatatan setiap perkawinan sama halnya dengan pencatatan suatu peristiwa hukum dalam kehidupan seseorang misalnya kelahiran, kematian yang dinyatakan dalam daftar pencatatan yang disediakan oleh Dinas Kependudukan dan Pencatatan Sipil.20

Pencatatan perkawinan adalah perbuatan administrasi berdasarkan peraturan perundang-undangan yang berlaku yang dilakukan oleh instansi yang berwenang: KUA bagi yang beragama Islam dan Kantor Catatan Sipil bagi yang beragama selain Islam, ditandai dengan penerbitan akta nikah untuk kedua pasangan suami istri. Pencatatan perkawinan sangat diperlukan agar terhindar dari madharat. Bukti tertulis ini dapat memproses secara hukum berbagai persoalan rumah tangga, terutama sebagai alat bukti sah di pengadilan. Pencatatan perkawinan dalam KHI (Kompilasi Hukum Islam) dijelaskan dalam pasal 5, yaitu:21

1) Agar terjamin ketertiban perkawinan bagi masyarakat Islam setiap perkawinan harus dicatat.

19 Herianto, "Analisis Hukum Pelaksanaan Pelayanan Kartu Keluarga dan Kartu Tanda Penduduk Pada Kantor Dinas Kependudukan dan Catatan Sipil Kabupaten Bone” (Skripsi-Universitas Hasanuddin, 2018).

20 Mohd. Idris Ramulyo, Hukum Perkawinan Islam Suatu Analisis dari Undang-Undang Nomor 1 Tahun 1974 dan Kompilasi Hukum Islam (Jakarta: Bumi Aksara, 1996), 243. 21 Undang-Undang Republik Indonesia Nomor 1 Tahun 1974 Tentang Perkawinan dan Kompilasi Hukum Islam (Grahamedia Press, 2014), 335. 
2) Pencatatan perkawinan sebagaimana tersebut pada ayat (1) dilakukan oleh Pegawai Pencatat Nikah sebagaimana diatur dalam Undang-Undang Nomor 22 Tahun 1946 juncto Undang-Undang Nomor 32 Tahun 1954.

\section{Administrasi Kependudukan}

Administrasi kependudukan merupakan rangkaian kegiatan penataan dan penertiban dokumen serta data kependudukan melalui pendaftaran penduduk, pencatatan sipil, pengelolaan informasi administrasi kependudukan serta pendayagunaan hasilnya untuk pelayanan publik. Penduduk dalam sistem administrasi kependudukan mempunyai hak sebagai berikut:22

1. Dokumen kependudukan

2. Pelayanan yang sama dalam pendaftaran penduduk dan pencatatan sipil

3. Perlindungan atas data pribadi

4. Informasi mengenai data hasil pendaftaran penduduk dan pencatatan sipil atas dirinya atau keluarganya

5. Ganti rugi dan pemulihan nama baik sebagai akibat kesalahan dalam pendaftaran penduduk dan pencatatan sipil serta penyalahgunaan data pribadi oleh instansi pelaksana.

Kewajiban penduduk dalam sistem administrasi kependudukan yaitu melaporkan setiap peristiwa penting yang dialami penduduk, seperti kelahiran, kematian dan perkawinan ke instansi pelaksana. Peristiwa penting tersebut akan membawa akibat terhadap penerbitan atau perubahan kartu keluarga, kartu tanda penduduk dan atau surat keterangan kependudukan lain yang meliputi pindah datang, perubahan alamat, atau status tinggal terbatas menjadi tinggal tetap. Informasi kependudukan berperan penting dalam penyelenggaraan pemerintahan dan pembangunan, sebab data administrasi penduduk adalah aset bangsa atau pemerintah daerah sebagai dasar perencanaan pembangunan. 23

Pemerintah mengembangkan sistem informasi administrasi kependudukan (SIAK) untuk mendukung efektifitas dan efisiensi

22 Fulthoni, et al., Memahami Kebijakan Administrasi Kependudukan (Jakarta: ILRC, 2009), 2.

23 Ibid., 3. 
penerbitan nomor induk keluarga (NIK) dan penerapan e-KTP. Perekaman database masyarakat saat ini telah menggunakan perlengkapan informasi teknologi dan komunikasi yang handal, cepat serta didukung sumber daya manusia yang sesuai dengan perkembangan zaman. Pelayanan administrasi kependudukan melalui SIAK online jauh lebih baik dengan sistem manual. Seluruh data kependudukan masyarakat telah di masukkan terlebih dahulu untuk disimpan setelah itu baru dicetak berdasarkan format yang sudah disedikan dalam SIAK online tersebut.24

Undang-Undang Nomor 24 Tahun 2013 Tentang Perubahan Atas Undang-Undang Nomor 23 Tahun 2006 Tentang Administrasi Kependudukan menjelaskan bahwa sistem informasi administrasi kependudukan selanjutnya disingkat SIAK adalah sistem informasi yang memanfaatkan teknologi informasi dan komunikasi untuk memfasilitasi pengelolaan informasi administrasi kependudukan di tingkat penyelenggara dan instansi pelaksana sebagai satu kesatuan.25 Komponen sistem informasi administrasi kependudukan (SIAK) berupa pencatatan sipil adalah sarana untuk mencatat peristiwa penting yang dialami penduduk untuk diterbitkan dokumen yang sah menurut hukum dalam bentuk akta catatan sipil yang dilegalisir oleh negara. Peristiwa penting yang harus dilaporkan penduduk terdiri dari kelahiran, kematian, perkawinan, perceraian, pengakuan anak, pengesahan anak, pengangkatan anak, perubahan nama, perubahan status kewarganegaraan dan lain-lain terkait peristiwa kependudukan.

Tertib administrasi kependudukan dapat memberi manfaat kepada berbagai pihak, baik individu, pemerintah maupun pihak yang berkepentingan diantaranya adalah:26

1. Bagi individu yang mendaftarkan dan mencatatkan peristiwa penting yang dialami akan mendapatkan kepemilikan dokumen

24 Raja Ilyas Aman, et al., "Perbandingan Kualitas Pelayanan Administrasi Kependudukan", Jurnal Kebijakan Publik, vol. 3, no. 1 (2012), 20.

25 Undang-Undang Nomor 24 Tahun 2013 Tentang Perubahan Atas UndangUndang Nomor 23 Tahun 2006 Tentang Administrasi Kependudukan.

26 Dwi Sadono, "Sensus Daerah Mengembangkan Sistem Administrasi Kependudukan Dalam Rangka Otonomi Daerah”, Jurnal Transdisiplin Sosiologi, Komunikasi dan Ekologi Manusia, vol.1, no.3 (2007), 8. 
kependudukan, seperti akta kelahiran, akta perkawinan, surat keterangan dan lainnya agar memperoleh keabsahan dan kepastian status hukum dirinya. Sehingga memudahkan yang bersangkutan memperoleh pelayanan publik sesuai haknya sebagai warga negara.

2. Bagi pemerintah diperlukan untuk pengesahan peristiwa penting yang dialami penduduk dan keperluan statistik kependudukan. Data hasil pendaftaran dan pencatatan administrasi kependudukan tersebut dihimpun, diolah, serta dianalisis untuk memperoleh suatu informasi kependudukan yang lebih akurat dibandingkan dengan sumber data yang lain.

3. Bagi pihak-pihak lain, melalui pembuatan statistik kependudukan yang berdasarkan data pencatatan peristiwa penting, dapat memberikan informasi berbagai macam kegiatan, seperti pelayanan kesejahteraan sosial, perbankan, bisnis dan asuransi. Menghimpun data kematian menurut jenis kelamin dan umur dapat dibuatkan tabel kematian yang berguna sebagai prediksi kependudukan di masa mendatang.

Sistem informasi administrasi kependudukan terdiri dari tiga komponen, yakni pendaftaran penduduk, pencatatan sipil sejak lahir hingga meninggal dunia dan pengelolaan informasi. Pendaftaran penduduk merupakan sarana untuk membangun basis data dan menerbitkan dokumen penduduk melalui kegiatan penerbitan kartu keluarga. Kartu keluarga merupakan kartu identitas keluarga yang memuat data tentang susunan, hubungan dan jumlah anggota keluarga yang wajib dimiliki oleh setiap keluarga seluruh Indonesia, dicetak rangkap tiga yang masing-masing dipegang oleh kepala keluarga, ketua Rukun Tetangga (RT) dan kantor kelurahan.27

Persyaratan yang harus dilengkapi dalam membuat kartu keluarga dijelaskan dalam Peraturan Presiden Republik Indonesia Nomor 96 Tahun 2018 Tentang Persyaratan Dan Tata Cara Pendaftaran Penduduk dan Pencatatan Sipil pasal 11 bahwa penerbitan kartu keluarga baru untuk penduduk WNI harus memenuhi persyaratan:28

27 Fulthoni, et al. Memahami Kebijakan, 12.

28 Peraturan Presiden Republik Indonesia Nomor 96 Tahun 2018 Tentang Persyaratan dan Tata Cara Pendaftaran Penduduk dan Pencatatan Sipil. 
1. Buku nikah/kutipan akta perkawinan atau kutipan akta perceraian

2. Surat keterangan pindah/surat keterangan pindah datang bagi penduduk yang pindah dalam wilayah Negara Kesatuan Republik Indonesia

3. Surat keterangan pindah luar negeri yang diterbitkan oleh Disdukcapil Kabupaten/Kota bagi WNI yang datang dari luar wilayah Negara Kesatuan Republik Indonesia karena pindah

4. Surat keterangan pengganti tanda identitas bagi penduduk rentan administrasi kependudukan

5. Petikan keputusan presiden tentang pewarganegaraan dan berita acara pengucapan sumpah atau pernyataan janji setia bagi penduduk WNI yang semula berkewarganegaraan asing atau petikan keputusan menteri yang menyelenggarakan urusan pemerintahan di bidang hukum tentang perubahan status kewarganegaraan.

Kartu keluarga merupakan dokumen resmi, oleh karena itu tidak boleh mencoret, mengubah, mengganti, menambah isi data yang tercantum dalam kartu keluarga. Perubahan data wajib dilaporkan oleh kepala keluarga ke kelurahan selambat-lambatnya dalam jangka waktu 14 hari kerja. Dijelaskan dalam Peraturan Presiden Republik Indonesia Nomor 96 Tahun 2018 Tentang Persyaratan dan Tata Cara Pendaftaran Penduduk dan Pencatatan Sipil pasal 12 Penerbitan KK karena perubahan data harus memenuhi persyaratan yaitu KK lama dan surat keterangan/bukti perubahan peristiwa kependudukan dan peristiwa penting.29

Peraturan Presiden Republik Indonesia Nomor 96 Tahun 2018 Tentang Persyaratan dan Tata Cara Pendaftaran Penduduk dan Pencatatan Sipil pasal 13 menjelaskan bahwa:30

1) Penerbitan KK karena hilang atau rusak bagi penduduk WNI harus memenuhi persyaratan:

a. Surat keterangan hilang dari kepolisian atau KK yang rusak; dan

29 Peraturan Presiden Republik Indonesia Nomor 96 Tahun 2018 Tentang Persyaratan dan Tata Cara Pendaftaran Penduduk dan Pencatatan Sipil. 30Ibid. 
b. KTP-el.

2) Penerbitan KK karena hilang atau rusak bagi penduduk orang asing harus memenuhi persyaratan:

a. Surat keterangan hilang dari kepolisian atau KK yang rusak

b. Kartu izin tinggal tetap

c. KTP-el

Pelayanan pendaftaran penduduk seperti penerbitan KTP (kartu tanda penduduk) wajib dimiliki seseorang yang tinggal di Indonesia sebagai kartu identitas resmi setelah berusia lebih dari 17 tahun. Program KTP elektronik menggantikan KTP yang lama sebagai bentuk pelayanan pemerintah kepada masyarakat dengan menyesuaikan teknologi informasi yang semakin berkembang. KTP elektronik merupakan dokumen kependudukan yang memuat sistem keamanan baik dari sisi administrasi maupun teknologi informasi pada database kependudukan nasional. Penduduk berhak memiliki satu KTP yang memuat nomor induk kependudukan (NIK) dan berlaku seumur hidup.31

Penjelasan terkait pengertian KTP elektronik tercantum dalam Peraturan Presiden Republik Indonesia Nomor 96 Tahun 2018 Tentang Persyaratan dan Tata Cara Pendaftaran Penduduk dan Pencatatan Sipil disebutkan bahwa KTP elektronik adalah kartu tanda penduduk yang dilengkapi dengan cip yang merupakan identitas resmi penduduk sebagai bukti diri yang diterbitkan oleh Dinas Kependudukan dan Pencatatan Sipil Kabupaten/Kota atau unit pelaksana teknis Dinas Kependudukan dan Pencatatan Sipil. Disebutkan juga dalam pasal 14 bahwa penerbitan KTP-el bagi penduduk WNI atau Penduduk Orang Asing terdiri atas:32

a. Penerbitan KTP-el baru

b. Penerbitan KTP-el karena pindah datang

c. Penerbitan KTP-el karena perubahan data

31Mahmuda Pancawisma Febriharini, "Pelaksanaan Program e KTP Dalam Rangka Tertib Administrasi Kependudukan”, Jurnal Ilmiah, vol. 5, no. 2 (2016), 2.

32Peraturan Presiden Republik Indonesia Nomor 96 Tahun 2018 Tentang Persyaratan dan Tata Cara Pendaftaran Penduduk dan Pencatatan Sipil. 
d. Penerbitan KTP-el karena perpanjangan bagi penduduk orang asing yang memiliki izin tinggal tetap

e. Penerbitan KTP-el karena hilang atau rusak

f. Penerbitan KTP-el di luar domisili

1) dalam keluarga

2) Kewarganegaraan

3) Dokumen imigrasi

4) Nama orang tua

5) Selain keterangan mengenai kolom isian sebagaimana dimaksud pada ayat (4) juga memuat kolom:

a. Tempat dan tanggal penandatanganan; dan

b. Nomenklatur, nama, Nomor Induk Pegawai dan tanda tangan kepala Disdukcapil kabupaten/kota

c. Nama dan tanda tangan kepala keluarga; dan

d. Keterangan 4 (empat) lembar rangkap untuk:

1) Kepala keluarga

2) Rukun tetangga atau nama lainnya

3) Desa/kelurahan atau nama lainnya

4) Kecamatan atau nama lainnya.

Terkait spesifikasi blangko dan formulasi kalimat kartu keluarga dijelaskan dalam lampiran Peraturan Menteri Dalam Negeri Nomor 118 Tahun 2017 Tentang Blangko Kartu Keluarga, Registrasi dan Kutipan Akta Pencatatan Sipil. Blangko kartu keluarga format baru terdapat penambahan kolom yang terdiri dari nomor, nama lengkap, NIK, jenis kelamin, tempat lahir, tanggal lahir, agama, pendidikan, pekerjaan, golongan darah, status perkawinan, tanggal perkawinan, status hubungan dalam keluarga, kewarganegaraan, dokumen keimigrasian dan nama orang tua. Letak perbedaan dari blangko keluarga yang lama adalah penambahan kolom tanggal perkawinan serta golongan darah.

Mengenai penulisan kartu keluarga dijelaskan dalam Peraturan Menteri Dalam Negeri Nomor 118 Tahun 2017 Tentang Blangko Kartu Keluarga, Registrasi dan Kutipan Akta Pencatatan Sipil Bab VIII Ketentuan Peralihan pasal 33 dijelaskan bahwa penulisan register dan kutipan akta pencatatan sipil harus menggunakan aplikasi SIAK paling lama 1 (satu) tahun setelah peraturan menteri ini diundangkan. Sejak diterbitkannya peraturan tersebut, kartu 
keluarga menggunakan model terbaru berbasis sistem informasi administrasi kependudukan (SIAK) versi 7. Kementerian Dalam Negeri mengeluarkan format SIAK versi 7 dengan penambahan kolom golongan darah, status perkawinan dan tanggal perkawinan. 33

Informasi administrasi kependudukan merupakan tanggung jawab pemerintah kabupaten atau kota yang secara pelaksanaannya diawali dari kelurahan sebagai awal pendataan penduduk dalam satu daerah. Data tersebut selanjunya disimpan dalam satu basis data yang terintegrasi secara nasional melalui jaringan internet. Sistem informasi administrasi kependudukan yang memanfaatkan teknologi informasi dan komunikasi untuk memfasilitasi pengelolaan data kependudukan di tingkat penyelenggara dan instansi pelaksana sehingga data tersebut menjadi tanggung jawab pemerintah pusat. Data tersebut menjadi satu kesatuan ke dalam satu pusat data (data center) di Direktorat Jenderal Administrasi Kependudukan.

SIAK versi 7 merupakan pengembangan aplikasi dari Direktorat Jenderal Kependudukan dan Pencatatan Sipil atau disingkat Ditjen Dukcapil dan telah beberapa kali dilakukan pengembangan versi untuk mengatasi permasalahan administrasi kependudukan. Pengembangan SIAK versi 7 sebagai langkah menuju tertib administrasi kependudukan seiring adanya perubahan aturan tentang penambahan kolom dalam blangko kartu keluarga. Aplikasi SIAK versi 7 ini menekankan pada status perkawinan seseorang, sehingga bisa diketahui dengan jelas tentang perkawinan tersebut sudah resmi dicatatkan menurut atauran negara atau hanya sah secara agama.

Format baru dalam blangko kartu keluarga di aplikasi SIAK versi 7 mengenai status perkawinan terdapat perubahan status yang terdiri dari kawin tercatat, kawin belum tercatat, belum kawin, cerai hidup dan cerai mati. Kelima status perkawinan tersebut bergantung pada kesiapan masyarakat untuk melakukan daftar ulang status perkawinannya. Sistem SIAK versi 7 mewajibkan masyarakat untuk melampirkan surat nikah atau akta perkawinan dalam melakukan pendaftaran pembuatan kartu keluarga, agar diregister kembali

33 Etik Wahyu Utami, Kepala Bidang Data dan Informasi, Dinas Kependudukan dan Pencatatan Sipil Surabaya, Wawancara, Surabaya 3 Mei 2019. 
nomor catatan perkawinannya menjadi kawin tercatat. Apabila masyarakat tidak dapat melampirkan akta perkawinan atau surat nikah maka dalam kartu keluarga akan tertulis menjadi kawin belum tercatat.

Persyaratan terkait penerbitan kartu keluarga juga dijelaskan dalam Peraturan Presiden Republik Indonesia Nomor 96 Tahun 2018 Tentang Persyaratan dan Tata Cara Pendaftaran Penduduk dan Pencatatan Sipil Bab VI Ketentuan Peralihan pasal 79 ayat 1 yang berbunyi penerbitan KK karena perubahan data untuk perkawinan yang belum dicatatkan sebelum peraturan presiden ini berlaku tetapi status hubungan dalam KK menunjukkan sebagai suami isteri dilaksanakan dengan persyaratan surat pernyataan tanggung jawab mutlak kebenaran data perkawinan yang ditandatangani kedua belah pihak dengan diketahui oleh 2 (dua) orang saksi.

Perubahan format baru dalam SIAK versi 7 untuk menambah status perkawinan yang semula kawin atau belum kawin menjadi kawin tercatat, kawin belum tercatat dan belum kawin merupakan salah satu kebijakan pemerintah sebagai wadah untuk mewakili permasalahan sosial yang banyak ditemukan di masyarakat. Salah satu persoalan tersebut adalah kawin belum tercatat, dan untuk menyelesaikan permasalahan lain. Adanya surat pernyataan tanggung jawab mutlak (SPTJM), memastikan kebenaran data perkawinan untuk mempercepat pengurusan perubahan data dalam kartu keluarga yang sebelumnya tertulis kawin, tetapi tidak bisa menunjukkan bukti surat nikah atau akta perkawinan. Ketentuan ini juga mempermudah proses pembuatan akta kelahiran bagi anak yang lahir dari perkawinan belum tercatat.

\section{Prosedur Penerbitan Kartu Keluarga di DISPENDUKCAPIL Surabaya}

Permohonan kartu keluarga baru bagi penduduk yang belum terekam data anggota keluarganya di pusat bank data kependudukan nasional harus memenuhi persyaratan sebagai berikut:34

1. Surat pengantar dari RT dan RW setempat

34Handoko, Kepala Seksi Perkawinan, Perceraian dan Status Kewarganegaraan, Dinas Kependudukan dan Pencatatan Sipil Surabaya, Wawancara (Surabaya: 3 Mei 2019) 
2. Melampirkan foto copy buku nikah atau akta perkawinan

3. Surat keterangan jaminan tempat tinggal dari pemilik rumah diketahui oleh RT dan RW

4. Akta kelahiran seluruh anggota keluarga

5. Surat keterangan pindah datang untuk penduduk yang pindah dalam wilayah negara Republik Indonesia

6. Surat keterangan datang dari luar negeri untuk penduduk yang datang dari luar negeri karena pindah

Proses selanjutnya penduduk yang ingin membuat kartu keluarga melapor ke kelurahan dengan membawa persyaratan dan mengisi formulir permohonan kartu keluarga. Petugas registrasi kelurahan selanjutnya mencatat dalam BHPPK (Buku Harian Peristiwa Penting dan Kependudukan). Proses yang terakhir yaitu lurah menandatangani formulir permohonan kartu keluarga. Pemohon selanjutnya meneruskan berkas formulir permohonan kepada camat sebagai dasar proses penerbitan kartu keluarga di kecamatan. Petugas kecamatan kemudian melakukan verifikasi dan validasi data penduduk.

Camat selanjutnya menandatangani formulir biodata penduduk WNI dan formulir permohonan kartu keluarga. Pemohon kemudian menyampaikan formulir permohonan kartu keluarga yang dilampiri dengan kelengkapan berkas persyaratan ke Dinas Kependudukan dan Pencatatan Sipil kota Surabaya. Petugas DISPENDUKCAPIL paling lambat selama tujuh hari kerja melakukan perekaman data ke dalam database kependudukan, selanjutnya kepala dinas menerbitkan dan menandatangani kartu keluarga baru tersebut. Adapun jumlah data pemegang kartu keluarga pada tahun 2018 PerKecamatan di kota Surabaya adalah sebagai berikut:35

Tabel 3.1

Daftar Pemegang Kartu Keluarga Per-Kecamatan Tahun 2018

\begin{tabular}{|c|l|c|}
\hline No & Nama Kecamatan & $\begin{array}{c}\text { Jumlah Pemegang } \\
\text { KK }\end{array}$ \\
\hline 1 & Karang Pilang & 23.665 \\
\hline
\end{tabular}

35 Etik Wahyu Utami, Kepala Bidang Data dan Informasi, Dinas Kependudukan dan Pencatatan Sipil Surabaya, W awancara (Surabaya: 3 Mei 2019). 
Amanda Zubaidah Aljarofi: Katagori Perkawinan Belum Tercatat......

\begin{tabular}{|c|l|c|}
\hline 2 & Wonocolo & 25.645 \\
\hline 3 & Rungkut & 36.248 \\
\hline 4 & Wonokromo & 52.949 \\
\hline 5 & Tegalsari & 34.116 \\
\hline 6 & Sawahan & 65.389 \\
\hline 7 & Genteng & 20.196 \\
\hline 8 & Gubeng & 46.552 \\
\hline 9 & Sukolilo & 35.133 \\
\hline 10 & Tambaksari & 74.049 \\
\hline 11 & Simokerto & 32.330 \\
\hline 12 & Pabean Cantian & 26.298 \\
\hline 13 & Bubutan & 33.788 \\
\hline 14 & Tandes & 29.347 \\
\hline 15 & Krembangan & 38.085 \\
\hline 16 & Semampir & 57.026 \\
\hline 17 & Kenjeran & 48.946 \\
\hline 18 & Lakarsantri & 18.538 \\
\hline 19 & Benowo & 19.768 \\
\hline 20 & Wiyung & 22.528 \\
\hline 21 & Dukuh Pakis & 19.659 \\
\hline 22 & Gayungan & 14.839 \\
\hline 23 & Jambangan & 16.334 \\
\hline 24 & Tenggilis Mejoyo & 18.884 \\
\hline 25 & Gunung Anyar & $18 . .103$ \\
\hline 26 & Mulyorejo & 28.332 \\
\hline 27 & Suko Manunggal & 33.064 \\
\hline 28 & Asemrowo & 14.009 \\
\hline 29 & Bulak & 13.695 \\
\hline 30 & Pakal & 16.708 \\
\hline 31 & Sambi Kerep & 20.047 \\
\hline & & \\
\hline
\end{tabular}

Perkembangan database kependudukan yang beralih ke sistem SIAK 7 mewajibkan masyarakat untuk melampirkan surat nikah atau akta perkawinan sebagai persyaratan penerbitan kartu keluarga. Bagi penduduk yang tidak bisa melampirkan akta perkawinan atau surat nikah maka dalam kartu keluarga tersebut dalam status 
perkawinannya tertulis kawin belum tercatat. Penduduk yang ingin melakukan perubahan data pada kartu keluarga selain membawa KK lama serta surat keterangan/bukti perubahan peristiwa kependudukan dan peristiwa penting diharuskan melampirkan akta perkawinan atau surat nikah agar diverifikasi kembali status perkawinannya pada aplikasi SIAK 7 sehingga status perkawinan dalam blangko kartu keluarga menjadi kawin tercatat.

Penduduk yang dulunya memiliki KK dan tertulis kawin pada status perkawinannya, namun tidak bisa membuktikan akta perkawinan atau surat nikah karena perkawinannya belum dicatatkan dapat melampirkan Surat Pernyataan Tanggung Jawab Mutlak kebenaran data perkawinan yang ditandatangani kedua belah pihak dengan diketahui dua orang saksi. Meskipun sudah melampirkan SPTJM, status perkawinannya tetap kawin belum tercatat dan tanggal perkawinan dalam blangko keluarga dikosongkan. Berbeda dengan penduduk yang melampirkan buku nikah atau akta perkawinan maka status perkawinan dalam blangko kartu keluarga akan tertulis kawin tercatat dan tanggal perkawinan tertulis sesuai yang tertera pada akta perkawinan atau surat nikah.

\section{Status Perkawinan Belum Tercatat dalam Blangko Kartu Keluarga Menurut Peraturan Perundang-Undangan yang Berlaku}

Instansi pelaksana bidang pelayanan administrasi kependudukan di kota Surabaya telah menerapkan format baru kartu keluarga sesuai dengan spesifikasi blangko dan formulasi kalimat kartu keluarga yang dijelaskan dalam lampiran Peraturan Menteri Dalam Negeri Nomor 118 Tahun 2017 Tentang Blangko Kartu Keluarga, Registrasi dan Kutipan Akta Pencatatan Sipil. Pelaksanaan pendataan administrasi kependudukan menggunakan SIAK berbasis online yang diterapkan pada tahun 2006. Sebelumnya, pendataan peristiwa penting kependudukan dilakukan secara manual melalui SIMDUK (Sistem Informasi Manajemen Kependudukan) yang belum memiliki standarisasi aplikasi dan 
pengawasan hanya di tingkat kabupaten/kota sehingga banyak ditemukan kelemahan dalam sistem ini.36

Sejak beralih ke SIAK seluruh pendataan terkait kependudukan berada di bawah pengawasan Direktorat Jenderal Kependudukan dan Pencatatan Sipil Kementerian Dalam Negeri Indonesia. Pengembangan aplikasi sistem informasi administrasi kependudukan (SIAK) yang selalu berubah sesuai kebutuhan dan kemajuan teknologi tidak hanya dirasakan manfaatnya oleh instansi pelaksana yang membidangi urusan administrasi kependudukan melainkan seluruh masyarakat Indonesia.

Sistem informasi administrasi kependudukan terus disempurnakan dari versi 1 sampai versi 5 yang menerapkan Kartu Tanda Penduduk (KTP) berbasis Nomor Induk Kependudukan (NIK) secara nasional. Aplikasi pada SIAK versi 5 terdapat pembaharuan yang terhubung langsung dengan database KTP elektronik dan pencetakan register akta kelahiran. Tampilan pada SIAK kemudian dikembangkan sesuai kebutuhan dan perkembangan teknologi, perubahan selanjutnya dalam kartu keluarga diatur dalam SIAK versi 6 yang berjumlah 15 kolom.

Bertambahnya jumlah penduduk di Indonesia menyebabkan pemerintah berusaha untuk mengetahui dan memperoleh data kependudukan secara akurat dan lengkap. Pemanfaatan media elektronik diperlukan untuk membuat pemetaan yang tepat agar mampu menanggulangi dan menyelesaikan permasalahan kependudukan. SIAK sebagai suatu sistem diharapkan mampu memenuhi hak-hak administratif penduduk dalam pelayanan publik serta memberikan perlindungan yang berkenaan dengan penerbitan dokumen kependudukan seperti pembuatan kartu keluarga.

Instansi pelaksana bidang pelayanan administrasi kependudukan sebagai pelayanan publik yang menerapkan kebijakan pemerintah, harus lebih cermat dalam melakukan pendataan terhadap masyarakat yang hendak membuat kartu keluarga, karena penulisan kartu keluarga menggunakan aplikasi SIAK 7. Menyesuaikan Peraturan Menteri Dalam Negeri Nomor 118 Tahun 2017 Tentang Blangko Kartu Keluarga, Registrasi dan

36 Etik Wahyu Utami, Kepala Bidang Data dan Informasi, Dinas Kependudukan dan Pencatatan Sipil Surabaya, Wawancara (Surabaya: 3 Mei 2019). 
Kutipan Akta Pencatatan Sipil Bab VIII Ketentuan Peralihan pasal 33, dijelaskan bahwa penulisan register dan kutipan akta pencatatan sipil harus menggunakan aplikasi SIAK paling lama 1 (satu) tahun setelah peraturan menteri ini diundangkan. Akibatnya, instansi pelaksana dituntut untuk memberikan sosialisasi terhadap masyarakat terkait penerapan aplikasi SIAK 7 yang menambah kolom golongan darah, tanggal perkawinan dan perubahan status perkawinan yang sebelumnya kawin atau belum kawin menjadi kawin tercatat, kawin belum tercatat dan belum kawin agar dicek ulang berkas persyaratan yang dibawa masyarakat untuk permohonan pembuatan kartu keluarga.

Aplikasi SIAK 7 mengharuskan masyarakat untuk melampirkan surat nikah atau akta perkawinan agar penerbitan blangko kartu keluarga tertulis kawin tercatat. Kebijakan baru dalam SIAK 7 mewajibkan masyarakat untuk melakukan daftar ulang status perkawinannya ke DISPENDUKCAPIL agar informasi dalam berkas kependudukan bisa diperbaharui. Proses daftar ulang dilakukan untuk memasukkan nomor catatan surat nikah ke dalam database kependudukan. Bagi pasangan suami istri yang sudah mencatatkan perkawinannya di KUA namun tidak melampirkan bukti akta nikah, maka konsekuensinya di anggap tidak memiliki akta nikah dari KUA kecamatan setempat sehingga dalam kartu keluarga tertulis kawin belum tercatat. Dengan demikian maka ada dua kemungkinan, yaitu pertama perkawinan itu belum tercatat di KUA dan yang kedua status perkawinannya sudah tercatat di KUA tetapi tidak melampirkan bukti akta perkawinan ketika mengurus pembuatan kartu keluarga yang baru.

Akan tetapi, secara pelaksanaan masih ada masyarakat yang tidak bisa membuktikan surat nikah atau akta perkawinannya, karena perkawinan yang dilakukan tidak tercatat sesuai peraturan perundang-undangan yang berlaku sehingga dalam kartu keluarga tertulis kawin belum tercatat. Dalam hal ini, pendataan kependudukan pada SIAK 7 meskipun dibolehkan melampirkan surat pernyataan tanggung jawab mutlak kebenaran data perkawinan sesuai Peraturan Presiden Republik Indonesia Nomor 96 Tahun 2018 Tentang Persyaratan Dan Tata Cara Pendaftaran Penduduk Dan Pencatatan Sipil pasal 79 ayat 1 sebagai pengganti akta 
perkawinan atau surat nikah sebaiknya tidak terlalu diutamakan agar tidak memberi peluang masyarakat untuk tidak mencatatkan perkawinannya.

\section{Analisis Yuridis Dijadikannya Kategori Perkawinan Belum Tercatat Sebagai Salah Satu Status Perkawinan dalam Blangko Kartu Keluarga}

Perkawinan merupakan peristiwa penting yang dipandang sebagai hubungan lahir batin antara seorang pria dan wanita yang telah memenuhi syarat untuk melangsungkan perkawinan. Untuk membuktikan adanya perkawinan, tidak cukup hanya dibuktikan dengan adanya peristiwa itu sendiri tanpa adanya bukti tertulis berdasarkan pencatatan di instansi pelaksana yang ditunjuk pemerintah. Melalui pencatatan tersebut kemudian ditindak lanjuti dengan dikeluarkannya akta perkawinan atau surat nikah oleh pejabat yang berwenang sebagai alat bukti sempurna (otentik).

Pencatatan perkawinan dalam konteks agama dan adat tidak menjadikan perkawinan itu menjadi tidak sah. Pencatatan perkawinan di Indonesia menjadi bagian dari hukum positif meskipun secara agama atau kepercayaan dianggap sah, namun perkawinan yang dilakukan di luar pengetahuan serta pengawasan pegawai pencatat nikah dianggap tidak sah. Dalam hal ini, perkawinan yang tidak dicatatkan tidak mempunyai kekuatan hukum di mata hukum negara. Aturan pencatatan perkawinan terdapat dalam Undang-Undang Nomor 1974 Tentang Perkawinan yang bersifat umum dan Kompilasi Hukum Islam (KHI) yang bersifat khusus, karena hanya diperuntukkan bagi masyarakat Indonesia yang memeluk agama Islam.

Akan tetapi, sejak diterbitkan peraturan baru terkait administrasi kependudukan yang dijelaskan dalam Peraturan Menteri Dalam Negeri Nomor 118 Tahun 2017 Tentang Blangko Kartu Keluarga, Registrasi dan Kutipan Akta Pencatatan Sipil terkait perubahan kolom pada kartu keluarga menjadikan pemerintah melakukan pengembangan terhadap aplikasi pendataan kependudukan dalam versi SIAK 7. Pendataan administrasi kependudukan dalam SIAK 7 mencantumkan status perkawinan belum tercatat dalam blangko kartu keluarga. Pengembangan aplikasi SIAK 7 ini menyebabkan status perkawinan penduduk lebih 
mudah diketahui mana yang sudah mencatatkan perkawinan menurut peraturan perundang-undangan yang berlaku atau hanya sah secara agama. Artinya, melalui kebijakan ini masyarakat yang tidak mencatatkan perkawinan pada pegawai pencatat nikah tetap mendapatkan hak administrasi kependudukan dengan mudah.

Kebijakan terkait pemenuhan hak administrasi kependudukan bagi perkawinan belum tercatat sangat bertentangan dengan peraturan perundang-undangan yang berlaku di Indonesia. Dalam Undang-Undang Nomor 1 Tahun 1974 Tentang Perkawinan telah dijelaskan, bahwa suatu perkawinan adalah sah apabila dilakukan menurut hukum masing-masing agama dan kepercayaannya itu dan di samping itu tiap-tiap perkawinan harus dicatat menurut peraturan perundang-undangan yang berlaku. Peraturan tersebut menjelaskan bahwa perkawinan hanya akan memiliki legalitas formal di hadapan hukum apabila dicatat oleh pegawai pencatat nikah (PPN) yang ditunjuk oleh negara, sementara yang tidak dicatatkan dianggap illegal menurut hukum. Akta perkawinan atau surat nikah yang diterbitkan melalui pencatatan perkawinan tersebut memudahkan suami istri untuk melakukan kebutuhan lain yang berkaitan dengan hukum.

Pencatatan perkawinan diatur dalam pasal 2 Peraturan Pemerintah Nomor 9 tahun 1975 yang menyatakan bahwa:

1) Pencatatan perkawinan dari mereka yang melangsungkan perkawinannya menurut agama Islam, dilakukan oleh pegawai pencatat sebagaimana dimaksud dalam UndangUndang Nomor 32 Tahun 1954 tentang pencatatan nikah, talak dan rujuk.

2) Pencatatan perkawinan dari mereka yang melangsungkan perkawinannya menurut agamanya dan kepercayaannya itu selain agama Islam, dilakukan oleh pegawai pencatat perkawinan pada kantor catatan sipil sebagaimana dimaksud dalam berbagai perundang-undangan mengenai pencatatan perkawinan.

Pencatatan perkawinan bagi umat Islam di Kantor Urusan Agama (KUA) akan terdata pada aplikasi SIMKAH (Sistem Informasi Manajemen Nikah). Penyajian data pada SIMKAH membangun jaringan yang terintegrasi antara KUA di tingkat daerah 
sampai kantor pusat. Data pada SIMKAH tersebut akan terintegrasi langsung pada aplikasi SIAK yang dikelola oleh Dinas Kependudukan dan Pencatatan Sipil, sehingga setiap masyarakat yang menikah sah sesuai administrasi negara atau hanya menikah secara agama dengan mudah diketahui. Bagi masyarakat yang beragama Katholik, Kristen, Budha dan Hindu pencatatan perkawinannya dilakukan di kantor catatatan sipil setelah kedua mempelai melakukan perkawinan menurut agamanya masingmasing.

Fungsi pencatatan perkawinan dalam hukum Islam yaitu agar seseorang memiliki alat bukti untuk membuktikan bahwa setiap orang benar-benar telah melakukan perkawinan. Pencatatan perkawinan bagi umat Islam di Indonesia diatur dalam KHI ( Kompilasi Hukum Islam) yang termuat dalam pasal 5 ayat 1 dan 2 sebagai berikut:

3) Agar terjamin ketertiban perkawinan bagi masyarakat Islam setiap perkawinan harus dicatat.

4) Pencatatan perkawinan sebagaimana tersebut pada ayat (1) dilakukan oleh Pegawai Pencatat Nikah sebagaimana diatur dalam Undang-Undang Nomor 22 Tahun 1946 jo.UndangUndang Nomor 32 Tahun 1954.

Kewajiban terkait pencatatan perkawinan bagi umat Islam juga diatur dalam Peraturan Menteri Agama Republik Indonesia Nomor 19 Tahun 2018 Tentang Pencatatan Perkawinan disebutkan dalam pasal 2 bahwa perkawinan antara seorang laki-laki dan seorang perempuan beragama Islam wajib dicatat dalam akta perkawinan. Pencatatan perkawinan bagi umat Islam dalam akta perkawinan sebagaimana disebut dalam pasal 2 dilakukan oleh Kepala KUA kecamatan. Pencatatan perkawinan pada lembaga yang ditunjuk pemerintah tentunya membuat seseorang memiliki dokumen resmi yang bisa dijadikan alat bukti dihadapan majelis persidangan apabila terjadi sengketa yang berkaitan dengan perkawinan, seperti waris, hak asuh anak, perceraian, nafkah dan lain sebagainya.

Pengembangan aplikasi sistem informasi administrasi kependudukan (SIAK) versi 7 di Indonesia memang memiliki dampak positif bagi pemerintah untuk mengetahui dan memperoleh data kependudukan secara akurat dan lengkap serta menjadikan hak- 
hak administrasi kependudukan masyarakat terpenuhi secara keseluruhan. Akan tetapi dampak negatif yang ditimbulkan dari pemenuhan hak administrasi bagi penduduk yang tidak mencatatkan perkawinannya dapat membuka peluang bagi masyarakat Indonesia untuk melakukan perkawinan tanpa pengawasan PPN dan hanya sah secara agama atau kepercayaan saja. Dokumen resmi negara yang dikeluarkan berupa kartu keluarga tersebut dapat memberikan perlindungan secara hukum bagi perkawinan belum tercatat, sehingga pencatatan perkawinan dapat dipandang sebagai persyaratan administratif yang tidak lagi memiliki legalitas formal di mata hukum.

Pencatatan perkawinan di Indonesia yang semula tidak bisa dilepaskan dari semangat untuk melakukan pembaharuan di bidang hukum keluarga yang menghendaki perbaikan status wanita untuk menghindari keburukan-keburukan akibat perkawinan seperti talak yang sewenang-wenang, poligami tanpa disertai keadilan, perkawinan paksa, serta melindungi hak-hak anak dari hasil perkawinan tersebut. Melalui pemberian hak administrasi kependudukan berupa kartu keluarga tanpa menyertakan akta perkawinan pada saat pendaftaran dan menambahkan keterangan kawin belum tercatat dalam blangko kartu keluarga bisa menyebabkan masyarakat tidak menghiraukan adanya kewajiban untuk mencatatkan perkawinan karena negara melalu Dinas Pendudukan dan Pencatatan Sipil memfasilitasi dokumen resmi negara berupa blangko kartu keluarga bagi perkawinan belum tercatat.

Kepemilikan kartu keluarga memiliki manfaat besar bagi penduduk, selain sebagai bukti sah dan kuat atas status identitas keluarga dan anggota keluarga akan kedudukan keberadaan kependudukan seseorang juga digunakan sebagai syarat penerbitan KTP, syarat pembuatan akta kelahiran bagi anak dan lain sebagainya. Adanya kartu keluarga tersebut menjadikan perkawinan belum tercatat diakui oleh pemerintah dan tidak memiliki perbedaan antara perkawinan tercatat. Dokumen resmi milik negara tersebut dapat digunakan sebagai dasar bagi pemenuhan hak warga negara yang lainnya dan bagi pemerintah menjadi dasar untuk pengambilan keputusan/kebijakan. 
Pengembangan database kependudukan yang beralih ke SIAK 7 ini secara tidak langsung menyebabkan kedudukan pencatatan perkawinan yang semula berfungsi untuk menjamin ketertiban hukum (legal order) sebagai instrumen kepastian hukum melalui alat bukti perkawinan, menjadi tidak tertib hukum karena dalam jangka panjang perkawinan belum tercatat tetap difasilitasi negara melalui pemenuhan hak administrasi kependudukan. Kemungkinan terburuk yang terjadi akibat penerbitan kartu keluarga bagi perkawinan belum tercatat adalah jumlah perkawinan tidak tercatat akan meningkat. Instansi pelaksana bidang pelayananan administrasi kependudukan selain dituntut lebih cermat dalam memeriksa berkas persyaratan permohonan kartu keluarga, sebaiknya menanyakan alasan masyarakat yang tidak bisa melampirkan akta perkawinan atau buku nikah agar disarankan mencatatkan perkawinannya melalui isbat nikah (pengesahan nikah) dan mengurus ulang pembuatan akta perkawinan atau surat nikah apabila kehilangan, agar dalam blangko kartu keluarga tidak tertulis kawin belum tercatat. Dengan demikian, negara tetap ikut andil dalam menekan angka peningkatan jumlah perkawinan belum tercatat dan meminimalisir terjadinya kawin belum tercatat.

\section{Penutup}

Dasar hukum dijadikannya kategori perkawinan belum tercatat sebagai salah satu status perkawinan dalam blangko kartu keluarga dijelaskan dalam Peraturan Menteri Dalam Negeri Nomor 118 Tahun 2017 Tentang Blangko Kartu Keluarga, Registrasi dan Kutipan Akta Pencatatan Sipil. Adapun terkait penulisan diatur dalam pasal 33 yang menyebutkan bahwa penulisan register dan kutipan akta pencatatan sipil harus menggunakan aplikasi SIAK paling lama 1 (satu) tahun setelah peraturan menteri ini diundangkan. Pengembangan aplikasi sistem informasi administrasi kependudukan (SIAK) versi 7 ini mencantumkan perubahan status perkawinan yang semula kawin dan belum kawin, sekarang menjadi kawin tercatat, kawin belum tercatat dan belum kawin.

Pengembangan database kependudukan yang beralih ke SIAK 7 ini secara tidak langsung menyebabkan kedudukan pencatatan perkawinan yang semula berfungsi untuk menjamin ketertiban hukum (legal order) sebagai instrumen kepastian hukum melalui alat 
bukti perkawinan menjadi bertentangan dengan kewajiban pencatatan perkawinan yang diatur dalam Undang-Undang Nomor 1 Tahun 1974 tentang Perkawinan. Pasal 2 Peraturan Pemerintah Republik Indonesia Nomor 9 Tahun 1975 Tentang Pelaksanaan Undang-Undang Nomor 1 Tahun 1974 tentang Perkawinan. Selain itu dijelaskan dalam KHI (Kompilasi Hukum Islam) yang termuat dalam pasal 5 yang menyatakan bahwa pencatatan perkawinan berfungsi sebagai alat ketertiban bagi umat Islam dan kewajiban pencatatan perkawinan yang termuat Peraturan Menteri Agama Republik Indonesia Nomor 19 Tahun 2018 Tentang Pencatatan Perkawinan yang disebutkan dalam pasal 2 menjadi tidak tertib hukum karena penulisan status kawin belum tercatat dalam blangko kartu keluarga.

\section{Daftar Pustaka}

Amir Syarifuddin, Hukum Perkawinan Islam Indonesia, Jakarta: Prenada Media, 2006.

Dwi Sadono, "Sensus Daerah Mengembangkan Sistem Administrasi Kependudukan Dalam Rangka Otonomi Daerah", Jurnal Transdisiplin Sosiologi, Komunikasi dan Ekologi Manusia, vol.1, no.3 (2007), 8.

Etik Wahyu Utami, Kepala Bidang Data dan Informasi, Dinas Kependudukan dan Pencatatan Sipil Surabaya, Wawancara, Surabaya 3 Mei 2019.

Fulthoni, et al., Memabami Kebijakan Administrasi Kependudukan, Jakarta: ILRC, 2009.

Handoko, Kepala Seksi Perkawinan, Perceraian dan Status Kewarganegaraan, Dinas Kependudukan dan Pencatatan Sipil Surabaya, Wawancara, Surabaya: 3 Mei 2019.

Herianto, "Analisis Hukum Pelaksanaan Pelayanan Kartu Keluarga dan Kartu Tanda Penduduk Pada Kantor Dinas Kependudukan dan Catatan Sipil Kabupaten Bone” , Skripsi--Universitas Hasanuddin, 2018.

Ita Musarrofa, Pencatatan Perkawinan di Indonesia, Surabaya: UIN Sunan Ampel Press, 2014.

Katrina, "Efektivitas Pelayanan Pembuatan Kartu Keluarga pada Dinas Kependudukan dan Pencatatan Sipil Kabupaten Tana Toraja", Skripsi--Universitas Hasanuddin,2017. 
Mahmuda Pancawisma Febriharini, "Pelaksanaan Program e KTP Dalam Rangka Tertib Administrasi Kependudukan”, Jurnal Ilmiah, vol. 5, no. 2 (2016).

Mohd. Idris Ramulyo, Hukum Perkawinan Islam Suatu Analisis dari Undang-Undang Nomor 1 Tahun 1974 dan Kompilasi Hukum Islam, Jakarta: Bumi Aksara, 1996.

Muizzatil Humairok, "Tinjauan Hukum Islam terhadap Pemenuhan Hak-Hak Perempuan dalam Perkawinan Sirri yang Ditangani LSM PEKKA Bangkalan”, Skripsi--IAIN Sunan Ampel Surabaya, 2012.

Mukhtamar Zamzami, Perempuan dan Keadilan dalam Hukum Kewarisan Indonesia, Jakarta: Kencana Prenada Media Group, 2013.

Neng Djubaedah, Pencatatan Perkawinan dan Perkawinan Tidak Dicatat Menurut Hukum Tertulis di Indonesia dan Hukum Islam, Jakarta: Sinar Grafika, 2012.

Peraturan Presiden Republik Indonesia Nomor 96 Tahun 2018

Tentang Persyaratan dan Tata Cara Pendaftaran Penduduk dan Pencatatan Sipil.

Raja Ilyas Aman, et al., "Perbandingan Kualitas Pelayanan Administrasi Kependudukan”, Jurnal Kebijakan Publik, vol. 3, no. 1 (2012).

Rosnidar Sembiring, Hukum Keluarga Harta-Harta Benda dalam Perkawinan, Jakarta: PT Raja Grafindo Persada, 2016.

Salman Alfarisi, "Komersialisasi Pernikahan Sirri dalam Prespektif Hukum Islam dan Hukum Positif (Studi Kasus Praktik Perkawinan Sirri di Desa Pekoren Kecamatan Rembang Kabupaten Pasuruan Provinsi Jawa Timur)", Skripsi--UIN Sunan Ampel Surabaya, 2018.

Sholah Hazmi, "Analisis Sad Al-Dhariah terhadap Perkawinan Bawah Tangan Studi Kasus Kelurahan Ujung Kecamatan Semampir Kota Madya Surabaya", Skripsi--UIN Sunan Ampel Surabaya, 2017.

Slamet Abidin, Fiqih Munakahat, Bandung: Pustaka Setia, 1999.

Tsuroya Kiswati, et al., Perkawinan di Bawah Tangan (Sirri) dan Dampaknya Bagi Kesejabteraan Istri dan Anak di Daerah Tapal Kuda Jawa Timur, Surabaya: Pusat Studi Gender IAIN Sunan Ampel, 2003. 
Amanda Zubaidah Aljarofi: Katagori Perkawinan Belum Tercatat.....

Undang-Undang Nomor 24 Tahun 2013 Tentang Perubahan Atas Undang-Undang Nomor 23 Tahun 2006 Tentang Administrasi Kependudukan.

Undang-Undang Republik Indonesia Nomor 1 Tahun 1974 Tentang Perkawinan dan Kompilasi Hukum Islam, Jakarta: Gramedia Press, 2014. 